\title{
Analisa Pengukuran Beban Kerja dengan Metode Stopwatch Time Study dan FTE di UD. Prasetya Rangga
}

\author{
Nurul Hudaningsih" ${ }^{* 1}$, Ismi Mashabai*2, Riki Prayoga ${ }^{3}$ \\ 1,2,3 Teknik Industri, Universitas Teknologi Sumbawa, Jl. Raya Olat Maras, Batu Alang, Moyo Hulu, \\ Pernek, Kabupaten Sumbawa, Nusa Tenggara Barat \\ e-mail: nurul.hudaningsih@uts.ac.id, ismi.mashabai@uts.ac.id, rikiprayoga22@gmail.com
}

\begin{abstract}
Abstrak
Di dunia industri yang semakin maju membuat para pelaku industri semakin berkompetitif dalam bersaing. Dalam persaingan dunia industri harus bisa mengatur sistem manjemennya dengan baik agar bisa dapat bersaing dengan industri lainnya. Masalah yang terjadi di home industry UD. Prasetya Rangga adalah terjadi ketidaksesuaian antara beban kerja dan jumlah pekerja yang mengakibatkantidak efisiensinya kerja juga peningkatan beban kerja. Penelitian ini bertujuan untuk mengukur waktu normal sebagai acuan perhitungan beban kerja sebagai dasar perhitungan jumlah tenaga kerja sekaligus membuat alur produksi. Metode yang digunakan FTE (Full Time Equivalent) untuk melakukan evaluasi kebutuhan tenaga kerja. Hasil dari penelitian ini didapatkan bahwa beban kerja yang diterima pada departemen pengadonan dan pencetakan yaitu 35\%, pada departemen pengovenan yaitu $146 \%$, beban kerja pada departemen packing yaitu 39\%. Dari hasil perhitungan metode FTE kebutuhan tenaga kerja yang optimal pada UD. Prasetya Rangga bagian produksi departemen pengadonan dan pencetakan jumlah tenaga kerja usulan adalah 1 orang sedangkan aktualnya adalah sebanyak 2 orang. Kemudian pada departemen pengovenan jumlah tenaga kerja usulan adalah 2 orang sedangkan aktualnya adalah 1 orang dan pada departemen packing jumlah tenaga kerja usulan adalah 1 orang sedangkan aktualnya adalah 2 orang.
\end{abstract}

Kata kunci: Beban Kerja, Home Industry,Metode FTE (Full Time Equivalent)

\begin{abstract}
Industry actors are more competitive in the sophisticated industrial world. They must be able to manage their management system properly, thus it would be able to compete with other industries in the competitive world. Problems that occur in the home industry UD. Prasetya Rangga is a mismatch between the workload and the number of workers that resulting inefficiency of work as well as the increase of workload. This study aims to measure normal time as a reference for calculating workload as a basis for calculating the amount of worker while creating a production flow. Method of this study used FTE (Full Time Equivalent) to evaluate workforce requirements. The results of this study revealed that the workload received at the printing and drafting department was $35 \%$ while the drafting department was $146 \%$, and the workload at the packing department was 39\%. Based on the calculation of the FTE method, the optimal workforce requirements at UD. Prasetya Rangga of the production department, the court, and the printing number of proposed workers was 1 person whereas the actual number is 2 people. Then, there were 2 people that were proposed in the drafting department while the actual number was 1 person and there was 1 person that were proposed in the packing department while the actual number was 2 people.
\end{abstract}

Keywords: FTE (Full Time Equivalent),HomeIndustry, Workload 


\section{PENDAHULUAN}

Di dunia industri yang semakin maju ini membuat para pelaku industri baik jasa maupun manufaktur semakin kompetitif dalam bersaing. Dalam persaingan di dunia industri harus bisa mengatur sistem manajemennya dengan baik agar bisa dapat bersaing dengan industri lainnya.UD Prasetya Rangga adalah salah satu perusahaan kecil(home industry) yang bergerak di bidang produksi roti. UD Prasetya Rangga berlokasi di Kecamatan Labuhan Badas Kabupaten Sumbawa yang telah berdiri sejak tahun 2011. Dalam aktivitas produksi roti UD Prasetya Rangga terbagi menjadi lima stasiun kerja yaitu pengadonan, pencetakan, pengovenan, quality control dan packing. Dalam sebuah perusahaan beban kerja seseorang sudah ditetapkan oleh perusahaan sesuai dengan Standar kerja dari perusahaan menurut jenis pekerjaan di tiap divisinya (Novera, 2010). Dengan Standar yang sudah ada dan jam kerja yang telah ditetapkan maka nantinya bisa ditentukan apakah karyawan dari suatu tempat bekerja sesuai dengan Standar yang sudah ditetapkan, dibawah Standar yang sudah ditetapkan atau diatas dari Standar yang sudah ditetapkan. Sehingga dengan mengetahui beban kerja yang dimiliki nantinya akan dapat menentukan kebutuhan karyawan dalam suatu bagian.

Berdasarkan permasalahan tersebut, perlu dilakukan pengukuran beban kerja sebagai dasar perhitungan kebutuhan tenaga kerja yang optimal. Perencanaan dan pengelolaan sumber daya manusia dapat dilakukan melalui analisis beban kerja. Menurut Marwansyah (2010), analisis beban kerja adalah proses untuk menetapkan jumlah jam kerja orang (manhours) yang dibutuhkan untuk merampungkan beban kerja dalam waktu tertentu.Analisa beban kerja sangat penting untuk menghitung tepatnya berapa banyak karyawan yang dibutuhkan untuk menyelesaikan semua tugas di bagian atau departemen pada perusahaan.

Dalam penelitian dilakukan identifikasi uraian aktivitas pekerjaan setiap pekerja, menganalisis beban kerja bagi setiap karyawan dan jumlah kebutuhan karyawan bagian produksi yakni dengan menggunakan metode FTE (Full Time Equivalent) yang merupakan salah satu metode yang digunakan dalam proses analisa beban kerja. Keunggulan metode FTE (Full Time Equivalent) ini dalam peningkatan produktivitas perusahaan yaitu dapat mengoptimalkan kinerja karyawan dan mengetahui jumlah karyawan yang optimal dibutuhkan perusahaan (Pambudi, 2017).Sehingga pada penelitian ini, peneliti menggunakan metode FTE (Full Time Equivalent) untuk melakukan evaluasi kebutuhan tenaga kerja. Menurut Dewi dan Satrya (2012), FTE (Full Time Equivalent) adalah salah satu metode analisis beban kerja yang berbasiskan waktu dengan cara mengukur lama waktu penyelesaian pekerjaan kemudian waktu tersebut di konversikan ke dalam indeks nilai FTE (Full Time Equivalent). Sedangkan menurut Adawiyah (2013), FTE (Full Time Equivalent) adalah metode dimana waktu yang digunakan untuk menyelesaikan berbagai pekerjaan dibandingkan terhadap waktu kerja ke jumlah orang yang dibutuhkan untuk menyelesaikan pekerjaan tertentu.

Pada penelitian yang dilakukan oleh Tridoyo dan Sriyanto (2014), membahas tentang identifikasi uraian pekerjaan pada bagian salesoperation region Semarang menghitung penggunaan waktu kerja pada setiap bagian, melakukan perhitungan beban kerja dengan metode Cross Sectional, serta mendapatkan info waktu waktu produktif pada proses. Hasil dari penelitian ini diketahui bahwa terdapat pendistribusian beban kerja yang kurang merata pada sales. Untuk meningkatkan kinerja karyawan PT Astra International Tbk- Honda Sales Operation region Semarang untuk level Administrator agar lebih efektif dan efisien dapat dilakukan dengan mengoptimalkan SDM dengan merubah komposisi jumlah tenaga kerja dan 
melakukan penyusunan kembali job-description pada bagian-bagian yang telah diukur beban kerjanya sehingga beban kerja yang ditanggung karyawan dapat terdistribusi dengan merata.

Pada Penelitian yang dilakukan oleh Gidion dan Adianto (2014) membahas tentang produktivitas karyawan dengan metode full time equivalent pada PT Astra Internasional divisi astra motor Jakarta Honda Center. Produktivitas karyawan JHC dapat dinilai berdasarkan nilai FTE yang telah di observasi. Hasil dari observasi menyatakan ada beberapa karyawan yang perlu ditambah beban kerjanya dan beberapa yang perlu ditinjau kembali jobdesc dari karyawan tersebut agar nilai FTE tidak melebihi 1.2 dan tidak dibawah 0.9 . Terdapat temuan di bagian mekanik dimana ada pekerja yang sering terlambat masuk setelah istirahat dan malas dan terdapat temuan di bagian partsmandimana terjadi kurangnya personel partsman sehingga terjadi penundaan pekerjaan administrasi.

Dan menggunakan metode Pengukuran waktu kerja. Pengukuran waktu kerja adalah suatu aktivitas untuk menentukan waktu yang dibutuhkan oleh seorang operator terampil dalam melaksanakan sebuah kegiatan kerja, yang dilakukan dalam kondisi dan tempo kerja yang normal(Wignjosoebroto, 1995). Tujuan Pokok dari aktivitas ini berkaitan erat dengan usaha menetapkan waktu baku/standar (standard time).

Afiani dan Pujitomo (2018) menggunakan metode Stopwatch Time Study untuk melakukan pengukuran kerja di CV Mans-group.Permasalahan yang sering terjadi pada CV.Mas-group ini adalah seringnya terjadi keterlambatan pengiriman ITC (Injector Tester \& Cleaner) kepada konsumen dikarenakan CV.Masgroup belum memiliki standar waktu pengerjaan ITC yang mempengaruhi lamanya produk sampai ke konsumen. Setelah melakukan perhitungan menggunakan metode Stopwatch Time Study didapatkan bahwa waktu baku proses pembuatan ITC adalah sebesar 4244,5 detik atau 70,7417 menit per produk.

Pada penelitian ini, metode pengukuran waktu kerja yang digunakan adalah pengukuran waktu kerja secara langsung dengan stopwatch time study. Penelitian dilakukan dengan cara mengamati dan mencatat waktu kerja operator dengan menggunakan stopwatch sebagai alat pengukur waktu, dimana pengukuran dilakukan untuk setiap elemen pekerjaan maupun satu siklus pekerjaan secara utuh, sehingga dapat diketahui berapa lama waktu yang dibutuhkan oleh seorang operator terampil pada kecepatan normal untuk mengerjakan suatu tugas tertentu. Waktu yang berhasil diukur dan dicatat kemudian dimodifikasikan dengan mempertimbangkan tempo kerja operator dan menambahkan faktor-faktor kelonggaran yang diberikan kepada operator.

Pengukuran waktu berguna untuk memilih cara kerja terbaik dari beberapa alternatif yang diusulkan, waktu yang dipakai sebagai patokan (standar) adalah waktu yang diperlukan untuk menyelesaikan pekerjaan dengan pengerjaan terpendek (tercepat).Untuk kelancaran kegiatan pengukuran dan analisis, maka selain stopwatchsebagai timing device diperlukan time study from guna mencatat data waktu yang diukur, serta untuk mencatat segala informasi yang berkaitan dengan aktivitas yang diukur tersebut seperti sketsa gambar layout area kerja, kondisi kerja (kecepatan kerja mesin, gambar produk, nama operator, dan lain-lain) dan deskripsi yang berkaitan dengan elemental breakdown (dapat dilihat dalam prosedur pelaksanaan pengukuran waktu kerja).

Dari penjelasan tersebut dapat diketahui bahwa dalam merencanakan jumlah tenaga kerja harus disesuaikan dengan beban kerja yang ada agar tidak mengakibatkan kerugian atau pemborosan perusahaan yang akan berdampak pada persaingan harga produk. Sehingga penelitian ini bertujuan untuk mengukur waku normal sebagai acuan perhitungan beban kerja sebagai dasar perhitungan jumlah tenaga kerja sekaligus membuat alur produksi. Maka diharapkan dengan dilakukannya evaluasi waktu baku dan beban kerja, manajemen sumber daya menjadi lebih baik dan tenaga kerja produksi dapat di optimalkan. 


\section{METODE PENELITIAN}

\subsection{Jenis dan sumber data}

Dalam penelitian ini data yang digunakan adalah data:

1. Data Primer

Data yang diperoleh yaitu dengan melakukan pengamatan langsung dilapangan meliputi data pengukuran langsung pada divisi produksi roti sesuai dengan jam kerja yang diterapkan didalam perusahan yaitu 8 jam kerja.

2. Data Sekunder

Data sekunder adalah data tambahan yang relevan dengan penelitian ini. Diantaranya diperoleh dari pustaka serta literatur yang mendukung topik penelitian ini seperti buku-buku yang memuat teori-teori, jurnal, skripsi, ataupun hasil pencarian data yang dilakukan melalui browsing internet serta beberapa data yang diperoleh dari UD. Prasetya Rangga.

\subsection{Alat dan bahan}

Dalam Penelitian ini peneliti menggunakan beberapa alat bantu dan bahan sebagai berikut:

a. Alat

1. Laptop untuk melakukan proses pengolahan data dalam menyusun naskah penelitian.

2. Stopwacth untuk pengambilan data waktu siklus

3. Worksheet

4. kamera untuk dokumentasi penelitian.

b. Bahan

\subsection{Alur Penelitian}

Alur penelitian dapat dijelaskan sebagai berikut. 


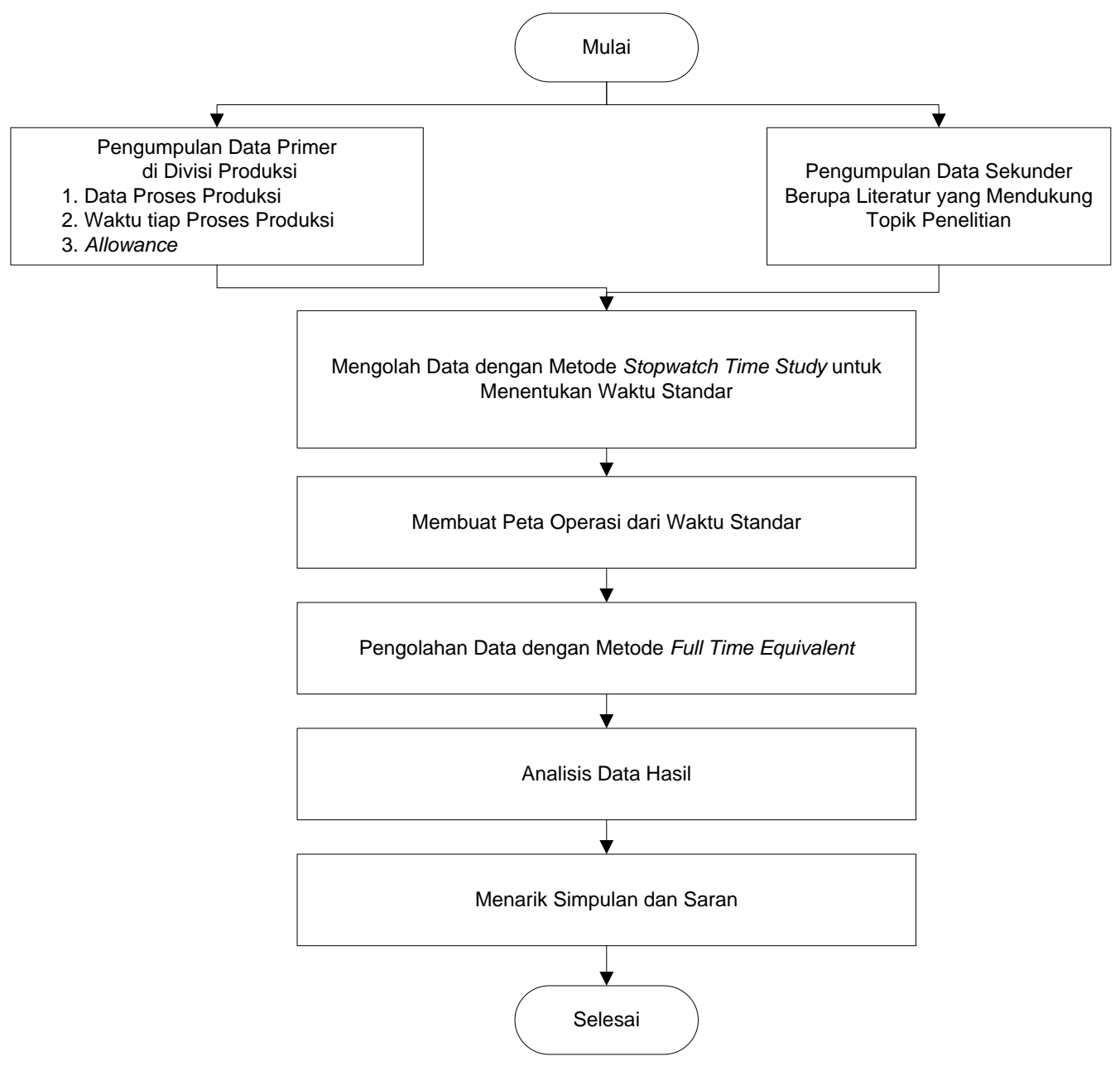

Gambar 1. Diagram Alur Penelitian Sumber: Hasil Penelitian

Alur penelitian berdasarkan flowchart diatas:

1. Mulai

Penelitian ini dimulai dengan mengidentifikasi masalah yang terjadi pada divisi produksi.

2. Mengumpulkan Data

Pengumpulan data berisikan data-data yang akan digunakan dalam penelitian ini.

Data yang dimaksud adalah semua informasi yang diperoleh

3. Data Primer

Data yang diperoleh yaitu dengan melakukan pengamatan langsung dilapangan meliputi data pengukuran langsung pada divisi produksi roti sesuai dengan jam kerja yang diterapkan didalam perusahan yaitu 8 jam kerja.

4. Data Sekunder

Data sekunder adalah data tambahan yang relevan dengan penelitian ini. Diantanya diperoleh dari pustaka serta literatur yang mendukung topik penelitian ini seperti buku-buku yang memuat teori-teori, jurnal, skripsi, ataupun hasil pencarian data yang dilakukan melalui browsing internet serta beberapa data yang diperoleh dari UD. Prasetya Rangga.

5. Tahap berikutnya adalah mengolah data primer yang didapatkan dari penelitian di UD. Prasetya Rangga. 
Mengolah data menggunakan metode stopwatch time study. Pengumpulan data dapat dilakukan dengan menggunakan metode wawancara, observasi partisipatif dan dibantu dengan dokumen dari perusahaan. Dalam perhitungan waktu kerja akan dihitung waktu siklus, kemudian waktu normal, dan waktu baku(Wignjosoebroto, 2003).

\section{Waktu Siklus Rata -Rata (WS)}

Waktu siklus adalah lamanya waktu pelaksanaan yang dibutuhkan oleh pemegang jabatan untuk dapat menyelesaikan satu siklus kegiatan kerja yang dilakukan sesuai dengan deskripsi tahapan pelaksanaan tugas jabatanya. Baiasanya waktu siklus dibuat dalam satuan detik.

$W S=\frac{\Sigma X i}{N}$

Dimana :

Ws = Waktu Siklus Rata Rata

$\Sigma X i=$ Jumlah Waktu Siklus

$N=$ Jumlah Pengamatan

2. Waktu Normal (WN) / Normal Time (NT)

Waktu normal yaitu waktu yang secara wajar atau normal dibutuhkan untuk menyelesaikan satu siklus kegiatan kerja yang dilakukan sesuai dengan setip tahapan pelaksanaan tugas. Waktu normal diperoleh dari waktu siklus yang telah ditambahkan dengan rating factor. Biasanya waktu normal dibuat dalam satuan detik.

$W N=W s(1+$ Rating Factor $)$

Dimana :

WN : Waktu Normal

Ws :Waktu Silus

2. Waktu Baku (WB) / Standard Time (ST)

Waktu baku yaiu waktu ketetapan yang dibutuhkan oleh pemegang jabatan dalam mengerjakan kergiatannya. Waktu baku merupakan waktu tetap yang telah ditambahkan dengan faktor kelonggaran (allowance) yang diperoleh dari westinghouse.

$W B=W N(1+$ Allowance $)$

Dimana :

WB : Waktu Baku

WN : Waktu Normal 


\section{Allowance : Kelonggaran}

6. Membuat Peta Operasi

7. Pada tahap ini membuat peta operasi produksi UD. Prasetya Rangga dari waktu standar yang didapatkan dengan metode stopwatch time study

8. Menghitung nilai Full Time Equivalent

Pada tahap ini menghitung nilai beban kerja dari waktu standar dengan menggunakan metode Full Time EquivalentMetode perhitungan beban kerja dengan FTE (Full Time Equivalent)metode dimana waktu yang digunakan untuk menyelesaikan berbagai pekerjaan dibandingkan terhadap waktu kerja efektif yang tersedia. FTE (Full Time Equivalent) bertujuan menyederhanakan pengukuran kerja dengan mengubah jam kerja ke jumlah orang yang dibutuhkan untuk menyelesaikan pekerjaan tertentu (Adawiyah, 2013)Untuk mendapatkan nilai FTE (Full Time Equivalent) dari suatu proses kerja adalah sebagai berikut :

$\mathbf{F T E}=\frac{\text { Total Waktu Aktivitas (menit })+ \text { allowance }(\text { menit })}{\text { Total Waktu Tersedia(menit })}$.

Dimana :

a. Allowance $($ menit $)=$ Kelonggaran $\times$ Jumlah Hari Setahun $\times$ Jam Kerja Sehari

b. Total Waktu Aktivitas (menit) = Total Waktu Kegiatan Utama + Pendukung + Insidensial

c. Total Waktu Tersedia (menit) $=$ Jumlah Hari dalam Setahun $\times$ Jam Kerja

Sehari

9. Analisis

Setelah melakukan perhitungan pada masing - masing tahapan perhitungan dilakukan. Hasil dari perhitungan beban kerja dengan FTE akan mendapatkan jumlah karyawan dibagian produksi yang optimal. Dan akan diberikan usulan untuk analisis pengembangan Sumber Daya Manusia oleh Peneliti.

10. Kesimpulan

Bagian ini menjelaskan secara singkat mengenai jawaban dari rumusan masalah yang telah ditetapkan pada awal penelitian. Selain itu memberikan rekomendasi yang bisa dikembangkan oleh pemilik perusahaan.

11. Selesai

Penelitian selesai dilakukan

\subsection{Teknik Pengumpulan Data}

Pengumpulan data berisikan data-data yang akan digunakan dalam penelitian ini. Data yang diamksud adalah semua informasi yang diperoleh baik itu berupa data primer atau data yang diperoleh dari pengamatan secara langsung maupun berupa data sekunder yang didapatkan dari data yang telah diperoleh sebelumnya.

\subsubsection{Pengumpulan Data Karyawan}

Setelah Menyelesaikan Langkah - Langkah Sebelumnya, dilakukan langkah pengumpulan data operator yang terkait dengan Rumusan Masalah yang sebelumnya telah 
dirumuskan yaitu terkait penelitian yang sudah direncanakan seperti data jumlah karyawan, data elemen kerja, waktu kerja yang telah ditentukan pada penelitian ini.

\subsubsection{Pengumpulan Data Waktu Siklus}

Pada tahap Ini pengumpulan data waktu proses yang dikerjakan oleh setiap operator dan setiap elemen kerja didapatkan dari pengamatan langsung pada proses produksi roti. yang nantinya akan menjadi bahan pengolahan data. berikut ini adalah waktu siklus yang ingin diketahui :

1. Waktu Siklus Departemen Pengadonan

2. Waktu siklus Departemen Pencetakan

3. Waktu Siklus Departemen Pengovenan

4. Waktu Siklus Departemen Packing

\section{HASIL DAN PEMBAHASAN}

\subsection{Pengumpulan Data}

\subsubsection{Data dan Kapasitas Produksi}

Selama melaksanakan kegiatan observasi penelitian ini, peneliti melakukan pengamatan kegiatan di proses produksi roti dengan mengamati secara langsung selama 20 hari. Berikut rata-rata produksi rotiUD. Prasetya Rangga :

Tabel 1 Hasil Pengamatan Kapasitas Produksi

\begin{tabular}{cc}
\hline Pengamatan & Rata-rata produksi/hari \\
\hline 20 hari & 1.288 \\
\hline
\end{tabular}

Sumber : Penelitian

Pada table 1 menjelaskan bahwa rata-rata produksi dari UD Prasetya Rangga adalah sebanyak 1288 bungkus roti perhari.

\subsubsection{Jumlah Hari Tersedia}

Untuk melakukan perhitungan beban kerja maka memerlukan waktu kerja perusahaan. Berikut adalah jumlah hari yang akan digunakan dalam perhitungan beban kerja karyawan seperti yang ditunjukkan pada Tabel 2.

Tabel 2 Jumlah Hari Kerja

\begin{tabular}{ccc}
\hline Perhitungan & Jumlah & Satuan \\
\hline 1 Hari & 8 & Jam \\
\hline 1 Minggu & 6 & Hari \\
\hline 1 Bulan & 24 & Hari \\
\hline 1 Tahun & 288 & Hari
\end{tabular}

Sumber : UD. Prasetya Rangga Telah di Olah

\subsubsection{Tenaga Kerja}

UD Prasetya Rangga mempekerjakan karyawan Sebanyak 5 orang Karyawan berikut ini pembagiannya adalah sebagai berikut: 
Tabel 3Jumlah tenaga kerja bagian produksi

\begin{tabular}{ccc}
\hline NO & DEPARTEMEN & JUMLAH TENAGA KERJA \\
\hline 1 & Pengadonan dan pencetakan & 2 Orang \\
\hline 2 & Pengovenan & 1 Orang \\
\hline 3 & Packing & 2 Orang \\
\hline
\end{tabular}

Sumber : UD. Prasetya Rangga

\subsubsection{Elemen Kerja Produksi}

Pada departemen pengadonan dan pencetakan ini memiliki jumlah 2 karyawan dan masing karyawan memiliki elemen pekerjaan utama yang sama seperti pada tabel 4

Tabel 4 Data uraian elemen kerja departemen pengadonan dan pencetakan

\begin{tabular}{cc}
\hline NO & Aktivitas Utama (Harian) \\
\hline 1 & Menimbang Bahan Baku \\
\hline 2 & Meracik Bahan Baku \\
\hline 3 & Melakukan Pengadukan Pada Bahan Baku \\
\hline 4 & Membentuk adonan menjadi bulat \\
\hline 5 & Mengisi selai pada adonan \\
\hline 6 & Material Handling \\
\hline
\end{tabular}

Sumber : UD. Prasetya Rangga

Tabel 4 merupakan aktivitas-aktivitas utama dari karyawan didepartemen pengadonan dan pencetakan. Antara lain aktivitas-aktivitasnya yaitu menimbang bahan baku, meracik bahan baku, melakukan pengadukan pada bahan baku, membentuk adonan menjadi bulat dan mengisi selai pada adonan.

Pada tahap selanjutnya setelah aktivitas di departemen pengadonan dan pencetakan. Akan diantar kebagian pengovenan. Jumlah karyawan di departemen pengovenan yaitu satu orang karyawan.

Tabel 5 Data uraian elemen kerja departemen pengovenan

\begin{tabular}{cc}
\hline NO & Aktivitas Utama (Harian) \\
\hline 1 & Memasukkan loyang berisi roti ke oven \\
\hline 2 & Membolak balikan loyang agar masaknya merata \\
\hline 3 & Material Handling \\
\hline
\end{tabular}

Sumber : UD. Prasetya Rangga

Tabel 5 merupakan aktivitas-aktivitas utama dari karyawan didepartemen pengovenan. Antara lain aktivitas-aktivitasnya yaitu memasukkan loyang berisi roti ke oven dan membolak balikan loyang agar masaknya merata.

Pada Tahap selanjutnya melakukan packing pada roti terdapat 2 karyawan yang memiliki aktivitas pekerjaan yang sama. 
Tabel 4.6 Data uraian elemen kerja departemen packing

\begin{tabular}{cc}
\hline NO & Aktivitas Utama (Harian) \\
\hline 1 & Memasukkan roti kedalam plastik \\
\hline 2 & Memasukkan merk kedalam plastik roti \\
\hline 3 & Material Handling \\
\hline
\end{tabular}

Sumber : UD. Prasetya Rangga

Tabel 6 merupakan aktivitas-aktivitas utama dari karyawan didepartemen packing.Antara lain aktivitas-aktivitasnya yaitu memasukkan roti kedalam plastik dan memasukkan merk kedalam plastik roti.

\subsection{Pengolahan Data}

1. Peta Proses Operasi

Dari waktu standard yang telah didapatkan maka dapatdigambarkan dengan peta proses operasi untuk memudahkan melihat alur produksi roti UD Prasetya Rangga sebagai berikut:

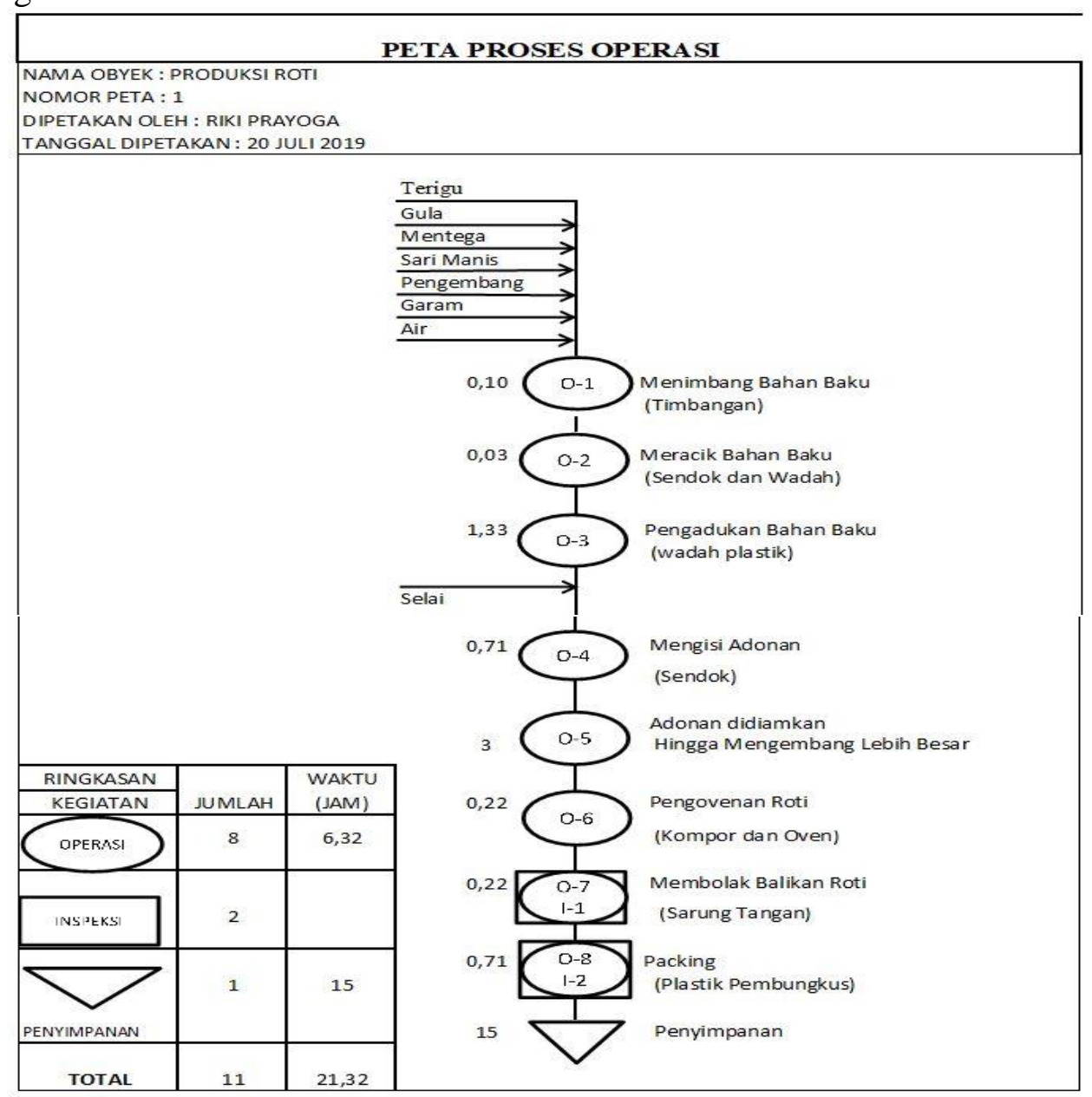

Gambar 2. Peta Proses Operasi Produksi Roti Sumber : Penelitian

Dari gambar 2 merupakan peta proses operasi dari produksi roti UD Prasetya Rangga. Pada tahap awal bahan baku yang sudah teredia ditimbang menggunakan timbangan dengan waktu 0,10 jam. Berikutnya bahan baku yang telah ditimbang diracik 
didalam sebuah wadah dengan waktu 0,03 jam. Lalu bahan baku yang sudah diracik tersebut dilakukan pengadukan selama 1,33 jam. Setelah bahan baku menjadi sebuah adonan maka dilakukan pengisian selai pada adonan tersebut dengan waktu 0,71 jam. Berikutnya adonan yang telah diisi selai didiamkan selama 3 jam agar adonan tersebut mengembang. Dan setelah adonan mengembang, adonan tersebut dimasukan kedalam sebuah oven dengan waktu 0,01 jam. Untuk menjaga agar adonan masaknya baik dengan cara membolak balikan adonan dengan waktu kegiatan selama 0,02 jam. Setelah adonan menjadi roti. Lalu dilakukan packing selama 0,71 jam. Roti yang sudah dipacking lalu disimpan selama 15 jam untuk selanjutnya dijual ke konsumen.

\section{FTE (Full Time Equivalent)}

Metode perhitungan beban kerja dengan Full Time Equivalent metode dimana waktu yang digunakan untuk menyelesaikan berbagai pekerjaan dibandingkan terhadapwaktu kerja efektifyang tersedia. Sehingga dengan menggunakan persamaan (2.1) diperoleh hasil hitungan sebagai berikut

a. Allowance

$=1,18 \%($ dapat dilihat pada tabel 4.14$) \times 288$ hari/tahun $\times 480 \mathrm{menit}$

$=1631,2$ menit

b. total waktu aktivitas

$=$ frekuensi $\times$ durasi (menit) $\times$ Jumlah hari kerja pertahun

$=1 \times 164,4$ menit $\times 288$ hari

$=47347,2$ menit

c. total waktu tersedia

$=288$ hari $\times 8$ jam $\times 60$ menit

$=138240$ menit

$$
\begin{aligned}
& F T E=\frac{47347,2+1631,2}{138240} \\
& F T E=0,35 \text { menit } / \text { tahun }
\end{aligned}
$$


Tabel 2. Nilai Full Time Equivalent Proses Produksi UD Prasetya Rangga

\begin{tabular}{|c|c|c|c|c|c|c|c|}
\hline $\begin{array}{l}\mathrm{N} \\
\mathrm{O}\end{array}$ & $\begin{array}{c}\text { DEPARTEME } \\
\mathrm{N}\end{array}$ & $\begin{array}{c}\text { INTENSITA } \\
\mathrm{S}\end{array}$ & $\begin{array}{c}\text { FREKUEN } \\
\text { SI }\end{array}$ & $\begin{array}{c}\text { WAKTU } \\
\text { STANDA } \\
\text { R } \\
\text { (MENIT) }\end{array}$ & $\begin{array}{c}\text { TOTAL } \\
\text { WAKTU } \\
\text { AKTIVITA } \\
\text { S (MENIT) }\end{array}$ & $\begin{array}{c}\text { TOTAL } \\
\text { WAKTU } \\
\text { TERSEDI } \\
\text { A } \\
\text { (MENIT) }\end{array}$ & $\begin{array}{c}\text { FT } \\
\text { E }\end{array}$ \\
\hline 1 & $\begin{array}{c}\text { Pengadonan } \\
\text { dan } \\
\text { Pencetakan }\end{array}$ & Harian & 1 & 164,4 & 47347,2 & 138240 & $\begin{array}{c}0,3 \\
5\end{array}$ \\
\hline 2 & Pengovenan & Harian & 11 & 2,9 & 9187,2 & 138240 & $\begin{array}{c}1,4 \\
6\end{array}$ \\
\hline 3 & Packing & Harian & 1 & 43,7 & 12441 & 138240 & $\begin{array}{c}0,3 \\
9\end{array}$ \\
\hline
\end{tabular}

\section{Sumber : Peneliti}

Pada tabel 2 menjelaskan bahwa pada departemen pengadonan dan pencetakan mendapatkan nilai FTE (Full Time Equivalent) sebesar 0,35 dimana ketika beban kerja ini ditarik menjadi persamaan kebutuhan tenaga kerja usulan dalam satu tahun yaitu 1 orang berdasarkan tabel Lalu pada departemen pengovenan mendapatkan nilai FTE (Full Time Equivalent) sebesar 1,46 dimana ketika beban kerja ini ditarik menjadi persamaan kebutuhan tenaga kerja usulan dalam satu tahun yaitu 2 orang berdasarkan tabel 2.1. Dan pada departemen packing mendapatkan nilai FTE (Full Time Equivalent) sebesar 0,39 dimana ketika beban kerja ini ditarik menjadi persamaan kebutuhan tenaga kerja usulan dalam satu tahun yaitu 1 orang berdasarkan tabel 2.1 .

3. Perhitungan Workload Analysis

Pada Bagian ini akan dilakukan analisa pada hasil pengolahan data menggunakan FTE (Full Time Equivalent) yang telah di lakukan pada bagian sebelumnya, sehingga hasil pengolahan data tersebut dapat mudah dipahami.

Tabel 3. Perhitungan Workload Analysis

\begin{tabular}{cccccc}
\hline No & Departemen & $\begin{array}{c}\text { Beban } \\
\text { kerjaFTE } \\
\text { (menit/tahun) }\end{array}$ & $\begin{array}{c}\text { Beban } \\
\text { KerjaFTE } \\
(\%)\end{array}$ & $\begin{array}{c}\text { Jumlah } \\
\text { Tenaga } \\
\text { KerjaAktual } \\
\text { (orang) }\end{array}$ & $\begin{array}{c}\text { Jumlah Tenaga } \\
\text { KerjaBerdasarkanPerhitungan } \\
\text { (orang) }\end{array}$ \\
\hline 1 & Pengadonan & 0,35 & $35 \%$ & 2 & 1 \\
\hline 2 & Pengovenan & 1,46 & $146 \%$ & 1 & 1
\end{tabular}

Sumber :Hasil Penelitian

Dari tabel 3 dapat diketahui nilai beban kerja setiap departemen secara keseluruhan guna menganalisis penyebab terjadinya tinggi rendahnya beban kerja yang dirasakan oleh karyawan. Dari ketiga departemen didapat data bahwa karyawan pada departemen 1 (Pengadonan dan pencetakan) dan departemen 3 (packing) memiliki beban yang 
underload. Sedangkan untuk departemen 2 (pengovenan) memiliki beban kerja yang overload. Maka dari itu perlu diadakannya pengurangan jumlah karyawan pada departemen 1 dan departemen 3. Dan untuk departemen 2 diadakannya penambahan jumlah karyawan.

\subsection{Analisis}

Analisis kebutuhan sumber daya manusia merupakan dasar perencanaan sumber daya manusia pada UD Prasetya Rangga. Perencanaan sumber daya manusia merupakan fungsi utama ang harus dilaksanakan pada sebuah organisasi. Hal ini diperlukan untuk menjamin mutu tenaga kerja, baik dari sisi kualitas dan kuantitas. Kesalahan dalam perencanaan sumber daya manusia dapat menimpulkan dampak negative pada UD Prasetya Rangga karena dapat memunculkan inefisiensi organisasi terutama terkait dengan pembiayaan tenaga kerja.

Hasil penelitian Analisis Beban Kerja dengan pendekatan berbasis Full Time Equivalent (FTE) di UD Prasetya Rangga memberikan gambaran bahwa terjadinya ketidakefektifan pekerjaan pada ketiga bagian tersebut. Peneliti menilai, bahwa jumlah tenaga kerja yang dipekerjakan di ketiga unit tersebut tidak mencerminkan waktu yang efisien terhadap beban kerja yang dihadapi. Berdasarkan hasil pengolahan data didapatkan bahwa karyawan pada departemen 1 (Pengadonan dan pencetakan) dan departemen 3 (packing) memiliki beban yang underload. Sedangkan untuk departemen 2 (pengovenan) memiliki beban kerja yang overload.

Dari hasil perhitungan tersebut perlu dilakukan pengaturan ulang terkait beban kerja karyawan agar didapatkan hasil yang optimal. Job Enrichment adalah perubahan mendasar dalam muatan dan kewajiban dari suatu pekerjan sehingga memberikan tantangan yang lebih besar bagi karyawan (Mondy 2008). Dari kondisi UD Prasetya Rangga saat ini, bisa dilakukan pengaturan ulang beban kerja karyawan. Ada beberapa pilihan yang dapat diterapkan pada UD Prasetya Rangga. Pilihan ke-1, menambah karyawan di departemen ke-2 dan mengurangi karywan di departemen ke-1 dan ke-3. Pilihan ke-2, karyawan pada departemen ke-1 dan departemen ke-3 memiliki beban kerja yang underload dan waktu pengerjaan tidak bersamaan. Sehingga pekerjaan pada departemen ke-3 dapat dialihkan kepada karyawan yang semula hanya mengerjakan tugas-tugas di departemen ke-1. Sedangkan karyawan yang semula di departemen ke-3 dapat mengerjakan sebagian tugas-tugas di departemen ke-2. Pilihan ke-3, karyawan di departemen ke-3 dapat diperbantukan untuk mengerjakan pekerjaan-pekerjaan di department ke-2 sehingga beban kerja di departemen ke-2 dapat berkurang. Namun Untuk pilihan pengaturan ulang beban kerja di setiap departemen diperlukan perhitungan tambahan untuk mencapai hasil yang optimal.

\section{KESIMPULAN}

Berdasarkan penelitian yang telah dilakukan di UD Prasetya Rangga bagian proses produksi dapat disimpulkan beban kerja yang diterima oleh masing - masing karyawan di setiap departemen adalah beban kerja pada proses produksi departemen pengadonan dan pencetakan yaitu $35 \%$, beban kerja pada departemen pengovenan yaitu $146 \%$, beban kerja pada departemen packing yaitu 39\%. Terdapat kelebihan tenaga kerja pada bagian departemen 1 (pengadonan dan pencetakan) dan departemen 3 (packing). Dan terdapat kekurangan tenaga kerja pada departemen 2 (pengovenan).Dari hasil perhitungan metode FTE. Kebutuhan tenaga kerja yang optimal pada UD Prasetya Rangga bagian produksi departemen pengadonan dan pencetakan jumlah tenaga kerja usulan adalah 1 orang, sedangkan aktualnya adalah 2 orang.Pada departemen pengovenan jumlah tenaga kerja usulan adalah 2 orang, sedangkan aktualnya adalah 1 orang. Pada departemen packing jumlah tenaga kerja usulan adalah 1 orang, sedangkan aktualnya adalah 2 orang. Selain 
pengurangan tenaga kerja, perlu dilakukan pengaturan ulang beban kerja pada masingmasing departemen untuk mencapai peningkatan efisiensi sekaligus efektivitas perusahaan.

\section{DAFTAR PUSTAKA}

Adawiyah, Sukmawati, 2013, Analisis Beban Kerja SumberDaya Manusia Dalam Aktivitas Produksi Komoditi Sayuran Selada (Studi Kasus Pada CV Spirit Wira Utama) : Jurnal Fakultas Ekonomi dan Manajemen, InstitutPertanian Bogor.

Afiani R dan Pujotomo D, 2017, Penentuan Waktu Baku DenganMetode Stopwatch Time Study StudiKasus CV.Mans Group : JurnalJurusan Teknik Industri, Fakultas Teknik, Universitas Diponegoro.

Dewi U. , Satrya, A.2012,Analisis Kebutuhan Tenaga Kerja Berdasarkan Beban Kerja Karyawan Pada PT PLN (persero) Distribusi Jakarta Raya dan Tangerang Bidang Sumber Daya Manusia dan Organisasi: Jurnal Jurusan Manajemen SDM Fakultas Ekonomi, Universitas Indonesia, Depok.

Gidion, Adianto, 2014, Pengukuran Produktivitas Karyawan Dengan Metode Full Time Equivalent (FTE) PT. Astra Internasional Tbk Divisi Astra Motor Penempatan Jakarta Honda Center :Jurnal Program Studi Teknik Industri, Universitas BundaMulia.

Marwansyah, 2010, Manajemen Sumber Daya Manusia Edisi Kedua. Bandung: Alfabeta.

Mondy RW. 2008. Manajemen Sumber Daya Manusia, Jilid 1 Edisi 10. Jakarta (ID): Erlangga.

Novera, 2010, Analisis Beban Kerja dan Kebutuhan Karyawan Bagian Administrasi Akademik dan Kemahasiswaan (Studi Kasus Unit Tata Usaha Departemen Pada Institusi Pertanian Bogor) :Jurnal Jurusan Teknik Industri, Fakultas Teknik, Institusi Bogor.

Pambudi YW, 2017,“Analisis Beban kerja Karyawan Dengan Metode Full Time Equivalent (Studi Kasus UKM Unlogic Projeck)". Jurnal Teknik Industri, Fakultas Teknologi Industri, Universitas Islam Indonesia Yogyakarta.

Tridoyo, Sriyanto, (2014), Analisis Beban Kerja Dengan Metode Full Time Equivalent Untuk Mengoptimalkan Kinerja Karyawan Pada PT. Astra International Tbk-Honda Sales Operation Region Semarang :Industrial Engineering Online Journal, Fakultas Teknik, Universitas Diponegoro

Wignjosobroto, 2008, Ergonomi, Studi Gerak dan Waktu, Guna Widya, Jakarta.

Wignjosoebroto, Sritomo, 2003, Ergonomi Studi Gerak dan Waktu, Cetakan Ketiga, Guna Widya, Jakarta. 